Application of Red Envelopes -New Weapon of WeChat Payment

\author{
Wei Liu $^{1, a}$, Xudong He ${ }^{2, b^{*}}$, Peiyi Zhang ${ }^{3, c}$ \\ ${ }^{1}$ Xuzhou Institute of technology, Jiangsu, China \\ ${ }^{2}$ Xuzhou Institute of technology, Jiangsu, China \\ ${ }^{3}$ Xuzhou Institute of technology, Jiangsu, China \\ a912362829@qq.com ${ }^{\text {b* }}$ guojimaoyi20030421@126.com ${ }^{\mathrm{c}} 394692813 @ q q . c o m$
}

Keywords: WeChat Payment; Red Envelopes; WeChat Marketing; Application

\begin{abstract}
The Tencent Inc. increases propagating WeChat payment through red envelopes to boost the WeChat payment recognized and used widely. With the help of two year's spring festival gala broadcast, red envelopes have become the new economy key words. In this paper, we discuss the present situation, significance and problems of red envelopes, rationally analysis the popularity of snatching red envelopes and remind users to avoid misunderstanding into red envelopes using.
\end{abstract}

\title{
Introduction
}

Except the "transport during the Spring Festival", "Spring Festival Gala" and the other same words, "snatching red envelopes" became the popular pop search term on the major media in 2015.And "snatching red envelopes" has become one of the most popular entertainment activities during the Spring Festival. As a result, there came out a behind operation mode, which let WeChat red envelopes come to us from all walks of life.

\section{The Present situation of WeChat Payment}

Business marketing strategy. The high popularity of WeChat red envelopes last year made Tencent aware of the hope of returning back to the success. This phenomenon was said to be like "the pearl harbor incident" by MaYun-the CEO of Ali Baba [1]. What's more the WeChat team and other business union launched at "shaking red envelopes" activities during Spring Festival, which sending out cash red envelopes about 5 billion RMB and 30 billion RMB discounting card.

Raising the ratings. The interaction between WeChat and 2015 Spring Festival Gala had been the main menu of spring festival feast. According to the data WeChat team announced officially, there were approximately 10.1 billion WeChat red envelopes been sent on spring Festival Eve. From 20.00 o'clock on 18th February to 0:48 o'clock on 19th, the WeChat "shaking-shaking" of spring festival were up to 110 billion times [2]. The others major television stations have followed this form, broadcasted at the same time, the issuance of red envelopes, and the audience can participate through "shaking-shaking" and other forms of.

The tool of sending 'Happy New Year' blessing. According to WeChat relevant responsible person, there are more and more people interested in WeChat red envelopes. The red envelopes are becoming a new tradition of New Year. For example, a young man called 'Xiao Yuan' who is a typical 'After 90s'.He received about 156 red envelopes while sending out 119 envelopes because he is a activated guy in company WeChat group.Xiaoyuan believed that the rule of snatching red envelopes is simple and equal, and he could be excited and happy when he received the lucky money while sending a new envelope to other colleagues with these money [3]. In his mind, when they are snatching lucky money, there's no gap between the old and the young, the leader and the subordinate and the red 
envelopes are just a symbol of 'happy new year', a tool sending good wishes to each other. Everyone is a family member then.

The way of showing love. By making public red envelopes to send "New Year Greeting" to the children who live in poor mountainous areas. During the Spring Festival this year, Tencent Public joint Chinese Poverty Alleviation Fund launched the "New Year Red Envelopes to send love" project. WeChat users click on the "my wallet - Tencent Public" to enter the page, through using your fingers, putting the picture in the circle of friends, ranging from the number of the amount of donations, the staff will exchange it for stationery, toys and other practical new year gift, which directly sent to poor mountainous area.

\section{Significance of WeChat red envelopes}

"Red Envelopes" why so red? Because it can bring the user's attention to businesses, bring convenience and fun to the users.

WeChat red envelopes very convenient. It is simple in design, users only need to enter the New Year Red Envelopes public number, choose the amount of money in the Red Envelopes, write blessing, through WeChat payment, Red Envelopes is finished, it can be sent to the group or individual. The other received red envelopes need to open it, WeChat payment can be associated with a bank card, the money which received will be automatic transfer after a working day. If you do not want to withdraw the cash, the money also can be directly used for the red envelopes, transfers, shopping, group purchase, recharge, buy movie tickets or lottery, plane tickets etc. For example when you participate in various meetings need to transfer collections, you can directly use chat window, or WeChat Wallet - transfer entrance to friends [4].

WeChat red envelopes can attract users. We Chat Red Envelopes through the "snatch" is a fun and interesting products like a game, especially in the process of the game with the money, it can stimulate people's spread desire. The Spring Festival is the traditional festival China. On the one hand, it holds traditional custom: go home reunion, buy new clothes, send red envelopes, and also continue to add new features. The big data technology provide for us to insight into these new trends [5]. We Chat Red Envelopes is a way which to attract young people to participate in. Chinese New Year red envelopes is the traditional custom, people through the custom make the New Year happier.

WeChat red envelope is a great social product. Red envelopes are social necessities. It means packet money wrapped in red paper; the way is the Chinese nation's traditional festivals, visit relatives and friends' treasure. In social occasions, we also can not be separated from the red envelope, marriage, appreciation, bonuses, official and even a casino, all need the red envelopes. This is China's most traditional way of interpersonal communication. People all over the China have sending red envelope tradition in the New Year [6], get married, or start to work. But now through WeChat which capacity of 600000000 users in such a virtual red envelopes, through social groups, and more popular why people are keen to red envelopes? Very simple thing, it is tacky to talking about money, a red envelope to cover his modesty. If someone helps you, you say, "I will transfer to your bank account" how strange? But it is inevitable to get great success by this kind of social network, not only because of how great WeChat red envelopes experience, but also the demand for receiving / sending packets since ancient times is very popular!

WeChat red envelope became popular quickly. On February 24, WeChat publish Chinese New Year red envelopes relevant date of 2015. From New Year's Eve to the fifth day of the first month, totally WeChat red envelopes transceiver 32.7 billion times, New Year's Eve day total of 1.01 billion times transceiver; WeChat transceiver during the Spring Festival peak individual envelopes in February 19 00: 00 to 00: 02, peaking at 1.65 million red packet per minute demolished open; and New Year's Eve WeChat send information total of 143 million times; WeChat circle of friends send a message 260 million times total. Shake the show interactive total more than 11 billion times; In 22:34 
Eve reached a peak 810 million times per minute. In the world 185 countries involved in the show WeChat shake (see Figure. 1). WeChat red packet arbitrary amount, sending the number of several objects, and its amount or average or random assignment, like "collective lottery", saying the electricity business sector, micro-channel is a red envelope viral marketing scheme [7].

\begin{tabular}{|c|c|}
\hline Date & Activity for snatching red envelopes \\
\hline Feb.9 & \multirow{2}{*}{$\begin{array}{l}\text { TFBOYS and Zhao Li-Ying (Chinese stars) send } 4 \text { million cash and } 80 \\
\text { million gift coupons for snatching red envelopes. }\end{array}$} \\
\hline Feb.10 & \\
\hline $\begin{array}{c}\text { Feb.11 } \\
\text { Lunar year }\end{array}$ & $\begin{array}{l}\text { Three whole point for grabbing red envelopes, } 30 \text { million cash and } 200 \\
\text { million gift coupons. Wu Qi-Long (film star)/Lei Jun (CEO of Xiaomi } \\
\text { Tech.), 10million cash and } 100 \text { million gift coupons. }\end{array}$ \\
\hline Feb.12 & $\begin{array}{l}3 \text { million cash, Li Xiang/Tong Liya 5million cash and } 80 \text { million } \\
\text { coupons }\end{array}$ \\
\hline Feb.13 & $\begin{array}{l}2.5 \text { million cash and } 25 \text { million gift coupons for red envelopes } \\
\text { snatching }\end{array}$ \\
\hline $\begin{array}{c}\text { Feb.14 } \\
\text { Valentine's Day }\end{array}$ & $\begin{array}{l}\text { Zhang Liang (man-model)/Li Lian-Jie (film star), } 15 \text { million cash and } \\
100 \text { million gift coupons }\end{array}$ \\
\hline Feb.15 & 2.5 million cash and 25 million gift coupons \\
\hline Feb.16 & \multirow{2}{*}{$\begin{array}{l}\text { MengNiu Corp. /Yan Qiang (compere) send } 2 \text { million cash and } 80 \\
\text { million gift coupons for red envelopes snatching activity. }\end{array}$} \\
\hline Feb.17 & \\
\hline $\begin{array}{c}\text { Feb.18 } \\
\text { New Year's Eve }\end{array}$ & $\begin{array}{l}\text { at ten a.m. and zero p.m. on New Year's Eve grabbing red envelopes } \\
\text { with } 110 \text { million cash and } 225 \text { million gift coupons inside; } 500 \text { million } \\
\text { cash in red envelope for Spring Festival gala interaction; Five whole } \\
\text { point for grabbing red envelopes with } 100 \text { million cash and } 200 \text { million } \\
\text { gift coupons. }\end{array}$ \\
\hline $\begin{array}{l}\text { Feb.19 } \\
\text { Spring Festiva- } \\
\text { Lantern Festival }\end{array}$ & $\begin{array}{l}5 \text { million cash, } 25 \text { million gift coupon, } 3.78 \text { million pieces of merchant } \\
\text { coupons; from the first day of Spring Festival to the Lantern Festival } \\
\text { many other stars successively send red envelopes with huge money. }\end{array}$ \\
\hline
\end{tabular}

Fig. 1 Activity for snatching red envelopes during Chinese Spring Festival

\section{Problems existing in the WeChat red envelopes}

WeChat red packet emerged a series of problems in the rapid spread, resulting in alienation of affection waste user time, threatening account, exchange deterioration, depressed mood.

The family increasingly alienated bowed their heads become a normalcy. The emergence of the mobile Internet, to facilitate interpersonal communication, ostensibly pulled into the emotional distance between people, but in fact we see the opposite is true. The emergence of WeChat, aggravate this situation .By the Chinese New Year, many people go home and reunite their family, who had a chat with nothing to fall back together, but now most of us who are in the bow brush WeChat or do other things [8]. In the rapid development of WeChat distance closer to the people, it is also alienating people away from the heart. New Year's Eve, "National snatch red" officially staged drama, a lot of people staffing a family phone, shaking red envelopes "Kaka" voices.

WeChat red envelopes waste users' time. Some groups on where I live, some people share advertising or other benefits because of the demands of the group from time to time to throw a few hundred dollars a red packet. This makes a lot of excited to the group of friends, in order to continue to get something for nothing satisfaction, many people are afraid to take the phone more, and gazed at the group waited red packet. In fact, time wasting a single minute; a person may one day to snatch the tens of dollars on the hundred dollars, but the loss of greater opportunity. Work hard day's work may not 
feel the gap, two days or three days, or even a month for two months, a waste of time to snatch red packet consequences will soon emerge, is really worth the candle. Therefore, advise every squat red micro-channel group snatch a friend, red is good not to be too greedy, daily waiting to snatch a red envelope in the group, it would be good to work, the sky did not fall pie, waste time and effort to snatch a red packet but also lost a real opportunity to make a fortune.

Network risks threaten account security. The identity information, bank accounts and other content bound by mobile phone in a WeChat account, if the encryption is not in place, the information might have been robbed by some technical means during wireless transmission. WeChat being an open social platform, users can freely share the link to their friends. Once the account is stolen, the bank card bound by WeChat account will face dangers of funds safety, as well as links to their friends. As a financing payment platform, internet financial institution is jointly established by multilateral credit network, each network node being intertwined and mutual interactive [9]. Any risks of some parts are likely spread to the entire network, even lead to serious financial system paralyzed.

Meanwhile, fast remote processing functions of the highly developed Internet technology may provide stronger technical support for the financial services products, but also speed up the process of risk accumulation, and even lead to the accumulation of risks and outbreaks. When purchasing in the mobile terminal, there may be encountered the mobile phone Trojans which could obtain the root privileges and accurately steal account password, or take advantage of the way of "transparent suspension layer" to steal directly payment password and other important information about payment system. In addition, there are a large number of mobile phones to be implanted Trojan virus that spread through unsafe application soft and small forums, search engine promotion. If you download these applications soft, the account password and verification code for payment will be stolen directly by Trojan creators. Maybe your pay account is likely to be falsely fraudulent.

Damage the normal exchange atmosphere. Due to the emergence of WeChat red envelope, a large group of friends produce a lot of unnecessary chat information. A few words are repeated but nothing more than "red envelopes quickly sent by Tyrants" "Tyrants sent again" "when Tyrants resend". Once Tyrants sent a red envelope, there is no normal communication but some flattery and insincere words to the sender of red envelope. Although the majority of users use WeChat under WiFi condition, there is still a lot of people use WeChat outdoors and much information flow data is wasted for nothing. But the waste of these flow data can not get anything of value in return, on the contrary, such behavior can drown the normal the atmosphere of communication. The WeChat users group will be destroyed if things continue this way.

Lead to depressed mood. A lot of people try to acquire the red with great expectations, but only snatching a small amount of money, even a few of cents because of "too many monks and too little gruel". And duration time of send is too short to snatch money for some reason such as mobile phone or internet speed that causes users' enthusiasm dropped sharply [10].

\section{How to avoid misunderstanding in red envelopes?}

Don't be addicted to snatch a red envelope. The Spring Festival holiday time is limited. We should make full use of these days to accompany wit our parents but not to spend more time to snatch red envelope with our mobile phones. We can talk more with our parents about our affairs, share our pleasure and sorrow in the life and work with them. We can also go to buy food and cook with our parents so as to increase feelings with them. It is also a good way of filial piety.

On security issues. Firstly, WeChat has perfect payment security mechanism with double protection- WeChat payment password and SMS verification code, as well as the risk control system of transactions. Users have to keep secret their own password and SMS verification code. Secondly, users can set gesture passwords of their WeChat wallet for active defense. Each time when you open the WeChat wallet, you must verify your gestures password before entering fully the payment system. 
Finally, the WeChat payment is ensured by the Chinese People's Insurance Company for full amount payment security. Any loss of property caused by using WeChat payment can acquire settlement of claims fleetly by contacting the customer service within 24 hours.

Businesses should consider the user's mood. Firstly, the amount of red envelope can not be too small, for that you can restrict the minimum amount of 5 Yuan or 10 Yuan. Secondly, you can set the delay measure to prevent first-come-first-serve so to take good care of all kinds of users. Moreover, the red envelope with 500 million Yuan is too small relatively to the 1.4 billion users. The amount of red envelope should be larger.

\section{Summary}

WeChat Red Envelope has already spread virally in our lives. It has more incomparable advantages but some problems. Snatching red envelope has its own frame. We have to objectively treat the fame of red envelope, rationally comment and participate. Additionally operators are able to expand the user group of red envelope, increase issuing models and extend activity time of red envelope so as to effectively resolve the security and compatibility problems, create a virtuous cooperation model of the industrial chain. The WeChat must have a broader space for development.

\section{Acknowledgements}

This research was funded by a research grant from the college students' Innovative training program, whose support is great appreciated.

\section{References}

[1] T. Zeng. Study on marketing thinking of the WeChat red envelope [J]. Market weekly (In Chinese), 4 (2014)76-77.

[2] Z. Xu. Impacts and implications on financial consumers by innovation and development of WeChat payment [J]. Zhejiang Finance (In Chinese), 6 (2014) 35-37.

[3] J.J. Wang. To view China's internet fraud crime problem from rend envelope event [J]. Railway Police College from WeChat red event (In Chinese), 4 (2014 ) 96-99.

[4] W. Zhao. Apparel corporations embrace WeChat [J]. China's Foreign Trade (In Chinese), 3(2014) 42.

[5] P.P. Zuo. Study on problems of WeChat marketing [J]. China Business \& Trade (In Chinese), 4 (2013) 24-26.

[6] J.S. Xiao. Study on WeChat marketing strategy of the new media era [J]. Commercial Times (In Chinese), 23 (2014) 30-33.

[7] L.Y. Wang. Introduction to advantages and development prospects of WeChat marketing [J]. Securities \& Futures of China (In Chinese), 9 (2013) 26-28.

[8]. Y. Wang. Analysis of mode and prospects of WeChat marketing [J]. Business p Economy (In Chinese), 9 (2014) 39-41.

[9] B. Yan. Thinking of WeChat marketing [J]. Medium-sized enterprise management and science technology (In Chinese), 7 (2014) 15-18.

[10] Y.J. Yang. Research on application of WeChat marketing in China [J]. Computer Knowledge and Technology (In Chinese), 27 (2014) 20-23. 